\title{
Pengaruh Polivinilpirolidon sebagai Polimer Mukoadhesif terhadap Sifat Fisik Patch Ekstrak Kulit Buah Delima (Punica granatum L.)
}

\author{
Rahmat A Hi Wahid ${ }^{a, 1 *}$ \\ a Program Sarjana Farmasi, Fakultas Sains dan Teknologi, Universitas PGRI Yogyakarta, Yogyakarta, DIY, Indonesia, 55 I82 \\ rahmat@upy.ac.id \\ *korespondensi penulis
}

\section{INFO ARTIKEL}

Diterima :

06-08-2020

Disetujui :

I4-08-2020

\section{Kata kunci:}

Polivinilpirolidon;

Ekstrak Kulit Buah Delima;

Patch.

\section{ABSTRAK}

Buah delima (Punica granatum L.) secara empiris digunakan untuk mengobati masalah gigi dan mulut seperti sariawan. Pengembangan obat sariawan berbasis herbal dengan bentuk sediaan patch dilakukan untuk mempertahankan waktu kontak antara zat aktif dengan bagian sariawan. Polivinilpirolidon (PVP) digunakan sebagai polimer karena sifatnya mukoadhesif sehingga mampu berikatan pada mukosa mulut. Penelitian ini bertujuan untuk mengetahui pengaruh penggunaan PVP sebagai polimer mukoadhesif terhadap karakteristik fisik sediaan patch yang mengandung ekstrak kulit buah delima (EKBD). EKBD diperoleh dengan metode maserasi. Konsentrasi EKBD yang digunakan adalah 5\% dan 10\%. Sedangkan konsentrasi polimer PVP yang digunakan yaitu 30,29\%, 33,04, 48,75\%, dan 65,5\%. Patch selanjutnya akan di evaluasi fisik yang meliputi keseragaman bobot dan dimensi ketebalan, $\mathrm{pH}$ permukaan, swelling, daya lekat, dan waktu lekat. Hasil menunjukkan bahwa patch yang mengandung ekstrak 10\% dengan tambahan polimer konsentrasi 30,29\% memiliki sifat yang cukup elastis disbanding dengan konsentrasi $48,75 \%$ dan $65,5 \%$. Sedangkan uji evaluasi fisik menghasilkan keseragaman bobot dan dimensi yang seragam, $\mathrm{pH} 6,63$, rata-rata indeks swelling 40,69\% $\pm \mathrm{I}$, dan rata-rata daya dan waktu lekat $13,50 \pm$ II,6. Dengan demikian dapat disimpulkan bahwa konsentrasi PVP terbukti berpengaruh pada sifat fisik patch yang dihasilkan.

\section{Key word:}

Polyvinylpyrrolidone;

Pomegranate Peel Extract;

Patch.

\section{ABSTRACT}

Pomegranate (Punica granatum L.) is empirically used to treat dental and mouth problems such as reccurent aphthous stomatitis (RAS). The development of RAS therapy based on herbal with patches dosage forms is carried out to maintain the contact time between the active substance and the RAS. Polyvinylpyrrolidone (PVP) is used as a polymer because it is mucoadhesive, so it can bind to the oral mucosa. Aimed to determine the effect of the use of PVP as a mucoadhesive polymer on the physical characteristics of patches preparations containing pomegranate peel extract (PPE). PPE was obtained by maceration method. The PPE concentration used were 5\% and I0\%. PVP concentration used were $30.29 \%, 33.04 \%, 48.75 \%$, and $65.5 \%$. The patches properties such as uniformity of thickness, $\mathrm{pH}$, swelling index, tensile and mucoadhesive strength. The results showed that patches containing 10\% extract and PVP concentration of $30.29 \%$ had sufficient elastic properties compared to both concentration. While the physical evaluation test obtained uniform weights and dimensions that are uniform, $\mathrm{pH} \mathrm{6.63,} \mathrm{the} \mathrm{average} \mathrm{swelling} \mathrm{index}$ is $40.69 \% \pm \mathrm{I} 6$, and the tensile and mucoadhesive strength is I3.50 \pm II.6. Altogether, the concentration of PVP is proven to affect the physical properties of the resulting patch.

This is an open access article under the CC-BY-SA license. 


\section{Pendahuluan}

Sariawan merupakan salah satu penyakit yang sering ditemui dalam masyarakat. Penyakit ini ditandai dengan adanya lesi atau luka berbentuk bulat putih pada mukosa mulut (Lewis dan Lamey, I998). Berdasarkan penelitian, sariawan disebabkan oleh beberapa faktor, diantaranya trauma lokal, bakteri, sistemik, nutrisi, genetik, alergi dan imunologi (Akintoye dan Greenberg, 2005). Lesi yang terbentuk pada sariawan sebenarnya dapat sembuh dengan sendirinya tanpa terapi pengobatan. Namun terbentuknya lesi sariawan dapat mengganggu aktifitas fisik penderita akibat rasa nyeri yang dialaminya. Oleh karenanya terapi pengobatan memang cukup diperlukan untuk mengatasi hal tersebut.

Dalam dunia medis, agen desinfektan dan anti inflamasi topikal telah banyak dikembangkan untuk mengatasi sariawan. Sediaannya dapat berupa mouthwash ataupun salep. Namun bentuk mouthwash ataupun salep dirasa masih kurang efektif dalam mengatasi sariawan karena penggunaannya yang mencakup seluruh rongga mulut dan singkatnya masa kontak antara zat aktif dengan bagian sariawan.

Sementara itu, dalam beberapa kurun terakhir ini telah banyak dikembangkan obat herbal seperti jinten hitam (Wahid dan Darmawan, 2020) dan buah delima. Kulit delima merupakan salah satu bagian tanaman yang telah banyak diteliti. Penelitian menunjukkan bahwa ekstrak kulit buah delima mengandung senyawa berfungsi sebagai antioksidan (Derakhshan et al., 2018) (Mphahlele et al., 2016) (Mastrodi Salgado et al., 20I2), anti bakteri (Abdollahzadeh et al., 20II) dan anti fungi (Nauli, 2010) (Glazer et al., 2012). Kandungan tersebut sangat diperlukan dalam mengatasi sariawan. Namun dibutuhkan suatu modifikasi agar ekstrak dapat menjadi sebuah sediaan yang dapat bekerja secara optimal mengatasi sariawan. Salah satu alternatif yang dinilai sesuai untuk aplikasi topikal pada jaringan mukosa adalah patch mukoadhesif.

Mukoadhesif memiliki banyak keuntungan seperti meningkatan retensi obat yang lama di tempat aksinya, onsetnya cepat, tingkat pelepasan obat yang terkontrol sehingga mendapatkan hasil terapi yang baik, meningkatkan kepatuhan pasien, dan periode perawatan yang relatif singkat (Shaikh et al., 20I I).

Karakteristik mukoadesif dari patch perlu didukung oleh penggunaan material yang sesuai, beberapa penelitian sebelumnya banyak memanfaatkan berbagai polimer sintetik, semisintetik, dan alami. Polivinilpirolidon (PVP) digunakan sebagai zat pengembang sehingga bermanfaat untuk meningkatkan pelepasan obat, meningkatkan elastisitas dan pembentuk lapisan film pada patch (Hashemi et al., 2017) sehingga diharapkan nantinya membantu memberikan efek yang cepat (efektif) dan potensial.

Penelitian ini bertujuan mengembangkan sediaan patch ekstrak kulit buah delima berbasis polivinilpirolidon yang dapat memberikan karakteristik fisik patch yang baik sebagai kandidat baru dalam pengobatan sariawan.

\section{Metode}

Penelitian ini merupakan penelitian yang dilakukan secara eksperimental laboratoris.

\section{Alat dan Bahan}

Alat - alat gelas yang lazim digunakan (Pyrex), penggaris, pipet ukur, pipet tetes, blender, saringan (Corong Buchner), sarung tangan, masker, jangka sorong, kamera digital, timbangan analitik, vacum rotary evaporator (IKA ${ }^{\circledR}$ RVIO),timbangan digital, kertas label, kertas saring, kapas dan selotip.

Bahan: kulit buah delima (Punica granatum L.) yang diperoleh dari Pakem Kaliurang, Yogyakarta, etanol 70\% (Brataco), Polivinilpirolidon, Pappermint, gliserin, tween 80, etanol 96\% dan aquadest.

\section{Jalannya Penelitian Ekstraksi kulit buah delima (Punica granatum L.)}

Pembuatan ekstrak ini menggunakan cara maserasi, yaitu dengan merendam serbuk simplisia buah delima dalam etanol $70 \%$ selama 24 jam. Cairan penyari akan menembus dinding sel dan masuk ke dalam rongga sel yang mengandung bahan zat aktif. Zat aktif akan larut karena adanya perbedaan konsentrasi antara zat aktif di dalam sel dengan yang di luar sel, maka larutan yang terpekat akan didesak ke luar. Kemudian disaring dan diulang 3 kali sehingga terjadi keseimbangan konsentrasi antara larutan di luar dan di dalam sel. Selanjutnya ampas dan filtrat dipisahkan. Filtrat jernih yang diperoleh diuapkan dengan Vacum rotary evaporator, pemanas water bath suhu $70{ }^{\circ} \mathrm{C}$ hingga diperoleh ekstrak yang kental. Tuangkan dalam cawan porselin, dipanaskan dengan pemanas water bath sambil terus diaduk. Proses ini untuk menguapkan etanol sehingga diperoleh ekstrak yang kental dengan konsentrasi I00\%. Selanjutnya untuk memastikan ekstrak mengandung zat aktif flavonoid yang diinginkan, maka akan dilakukan pengecekan kandungan ekstrak dengan metode KLT.

\section{Formulasi patch mukoadhesif}

Ekstrak yang diperoleh nantinya digunakan sebagai zat aktif dalam sediaan patch mukoadhesif. Sedangkan polimer yang digunakan adalah PVP. 
Bahan tambahan lainnya adalah gliserin, tween 80, peppermint, etanol $96 \%$ dan aquadest. Metode pelarutan akan digunakan dalam pembuatan formulasi ini. PVP dilarutkan dalam etanol 96\%. Setelah itu, semua bahan tersebut dicampur hingga homogen dan dikeringkan sampai terbentuk film. Secara umum tabel variasi komposisi formula dapat dilihat pada tabel I.

Tabel I.Variasi komposisi formula patch

\begin{tabular}{|c|c|c|c|c|c|}
\hline $\begin{array}{c}\text { For } \\
\text { mul } \\
\mathrm{a}\end{array}$ & $\begin{array}{l}\text { Zat } \\
\text { aktif } \\
(\%)\end{array}$ & $\begin{array}{l}\text { PVP } \\
(\%)\end{array}$ & $\begin{array}{c}\text { Pepper } \\
\text { mint } \\
(\%)\end{array}$ & $\begin{array}{l}\text { Twe } \\
\text { en }\end{array}$ & $\begin{array}{c}\text { Gliser } \\
\text { in }\end{array}$ \\
\hline FI & 10 & $\begin{array}{c}30,2 \\
9\end{array}$ & 5,19 & $\begin{array}{c}22,0 \\
8\end{array}$ & 5,19 \\
\hline $\mathrm{F} 2$ & 5 & $\begin{array}{c}19,7 \\
2\end{array}$ & 5,19 & $\begin{array}{c}22,0 \\
8\end{array}$ & 7,79 \\
\hline F3 & 5 & $\begin{array}{c}48,7 \\
5\end{array}$ & 2,5 & - & - \\
\hline F4 & I0 & 65,5 & 2,5 & - & - \\
\hline
\end{tabular}

\section{Uji evaluasi fisik}

Uji evaluasi fisik yang dilakukan meliputi :

I. Keseragaman bobot dan dimensi Masing masing patch ditimbang menggunakan timbangan digital yang selanjutnya diukur dimensi ketebalannya dengan menggunakan mikrometer sekrup.

2. Uji swelling

Patch sebagai berat kering (dry weight atau $\mathrm{Wd}$ ) diletakkan ke dalam test tube kemudian I,0 $\mathrm{ml} \mathrm{NaCl}$ fisiologis ditambahkan ke dalam masing masing test tube. Sampel kemudian diinkubasi dengan interval waktu tertentu pada suhu $37^{\circ} \mathrm{C}$. Setelah dikeluarkan dari inkubator, $\mathrm{NaCl}$ fisiologis dibuang dan dibilas menggunakan aquadest tiga kali. Sampel diletakkan di atas tisu untuk menghilangkan air yang menenpel sebelum ditimbang berat basahnya (wet weight atau $\mathrm{Ww}$ ). Besarnya \% swelling dihitung menggunakan persamaan berikut:

$$
\% \text { swelling }=\frac{W w-W d}{W d} \times 100
$$

3. $\mathrm{Uji} \mathrm{pH}$

Masing masing patch dibiarkan mengembang dalam I ml aquadest selama I jam dalam temperatur ruangan. Selanjutnya $\mathrm{pH}$ permukaan patch diukur dengan menggunakan $\mathrm{pH}$ meter.

4. Uji daya lekat dan waktu lekat Patch ditempel pada usus tikus yang sudah dilekatkan pada beaker glass. Beaker glass dimasukkan ke dalam wadah yang berisi cairan fisiologis $\mathrm{NaCl} \quad 0,9 \%$. Wadah kemudian diputar dengan magnetic stirer.

\section{Hasil dan Pembahasan Ekstraksi}

Proses ekstraksi menghasilkan hasil akhir berupa ekstrak kental berwarna kecokelatan.

\section{Formulasi patch}

Formulasi patch dilakukan dengan mengunakan metode pelarutan. Berdasarkan hasil formulasi pada tabel I, diperoleh patch dengan karakteristik yang cukup berbeda. Formula FI dan F2 menghasilkan patch yang tidak keras dan cukup elastis. Sedangkan Formula F3 dan F4 memiliki sifat yang keras, kurang elastis dan mudah rapuh.

Penggunaan PVP sebagai polimer yang larut dalam air menyebabkan pelepasan bahan terlarut lebih cepat dan mengurangi indeks swelling pada patch. Sehingga tekstur patch tidak mudah rapuh dan keras (Shaikh et al., 20II) (Samprasit et al., 2015) (Jaipakdee et al., 2018).

\section{Uji evaluasi fisik}

Keseragaman bobot dan dimensi yang diperoleh dari uji evaluasi fisik patch yaitu seragam, karena tidak tidak ada yang menyimpang dari 5\% - I0\% bobot rata-rata (Depkes RI, I979). Hasil uji $\mathrm{pH}$ yang memenuhi syarat $\mathrm{pH}$ mukosa yaitu patch dengan ekstrak $5 \%$, yaitu 6,63 , karena rentang $\mathrm{pH}$ mukosa manusia yaitu 5,6 -7 (Verma dan Chattopadhyay, 20I I), tetapi dari hasil uji $\mathrm{pH}$ ini masih perlu dilakukan optimasi $\mathrm{pH}$ kembali, karena setelah replikasi pengukuran $\mathrm{pH}$, penurunan $\mathrm{pH}$ tidak stabil. Pada $\mathrm{pH}<5,5$ akan terjadi demineralisasi yang menyebabkan kelarutan email hingga dapat menyebabkan karies gigi, sedangkan pada $\mathrm{pH}>5,5$ akan menyebabkan remineralisasi (Wirawan dan Puspita, 2017).

Sementara, untuk \% sweeling rata - rata $\pm \mathrm{SD}$ ekstrak 5\% yaitu $35,76 \% \pm 15,87$ dan rata - rata \pm SD ekstrak $10 \%$ yaitu 40, 69\% $\pm 16,37 \%$. Semakin tinggi \% sweeling, maka semakin tinggi kemampuan patch untuk menyerap cairan di lingkungannya, dan semakin mudah obat terlepas atau rilis dari bentuk sediaan obat (patch). Uji daya dan waktu lekat patch dengan ekstrak 5\% dan I0\% diperoleh masing - masing rata - rata $\pm \mathrm{SD}$ : $3 \mathrm{I}, 0 \mathrm{I}$ $\pm 9,72$ dan $\mathrm{I3}, 50 \pm$ II,6. Uji daya lekat dan waktu lekat patch yang ideal adalah diatas 180 menit (Khairnar et al., 2009). Uji ini merupakan bagian dari karakteristik fisik patch yang sangat penting apabila patch akan digunakan dalam aplikasi biomedis, karena merupakan faktor utama dalam 
sistem mukoadhesif (Kürklü-Gürleyen et al., 2016) (Bernkop-Schnürch, 2000).

\section{Simpulan dan Saran}

Ekstrak kulit buah delima dapat diformulasikan dengan polimer polivinilpirolidon (PVP) menjadi patch yang bersifat mukoadhesif dengan tambahan tween, peppermint dan gliserin. Konsentrasi PVP yang digunakan dapat mempengaruhi sifat fisik. Semakin tinggi konsentrasi PVP maka bobot dan dimensi, indeks mengembang (swelling), waktu dan daya lekat patch juga semakin meningkat.

Saran, Meskipun $\mathrm{pH}$ patch ini telah mendekati $\mathrm{pH}$ rongga mulut namun Optimasi $\mathrm{pH}$ masih perlu dilakukan lebih lanjut supaya sesuai dengan $\mathrm{pH}$ rongga mulut.

\section{Ucapan Terima Kasih}

Penulis ingin mengucapkan terima kasih kepada Pemerintah Republik Indonesia dan Universitas Muhammadiyah Yogyakarta. Penelitian ini disupport dan dibiayai oleh Direktorat Jenderal Pendidikan Tinggi Kementerian Pendidikan dan Kebudayaan Nomor: I35/SP2H/KPM/ DIT. LITABMAS/V/20I3.

\section{Daftar Pustaka}

Abdollahzadeh, S. et al. (20II) 'Antibacterial and antifungal activities of punica granatum peel extracts against oral pathogens.', Journal of dentistry (Tehran, Iran).

Bernkop-Schnürch, A. (2000) 'Chitosan and its derivatives: Potential excipients for peroral peptide delivery systems', International Journal of Pharmaceutics. doi: I0.1016/S0378-5173(99)00365-8.

Departemen Kesehatan Republik Indonesia. (I979). Farmakope Indonesia Edisi Ketiga. Jakarta.

Derakhshan, Z. et al. (2018) 'Antioxidant activity and total phenolic content of ethanolic extract of pomegranate peels, juice and seeds', Food and Chemical Toxicology. doi: I0.10I6/j.fct.2018.02.023.

Glazer, I. et al. (2012) 'Partial identification of antifungal compounds from Punica granatum peel extracts', Journal of Agricultural and Food Chemistry. doi: I0.102I/jf300330y.

Hashemi, M. et al. (2017) 'Formulation and optimization of oral mucoadhesive patches of myrtus communis by box behnken design', Advanced Pharmaceutical Bulletin. doi: I0.I5I7I/apb.2017.053.

Jaipakdee, N., Pongjanyakul, T. and Limpongsa, E. (2018) 'Preparation and characterization of poly (vinyl alcohol)-poly (vinyl pyrrolidone) mucoadhesive buccal patches for delivery of lidocaine HCL', International Journal of Applied Pharmaceutics. doi: I0.22I59/ijap.2018vIOiI.23208.

Khairnar, A. et al. (2009) 'Developmement of mucoadhesive buccal patch containing aceclofenac: In vitro evaluations', International Journal of PharmTech Research.

Kürklü-Gürleyen, E. et al. (2016) 'Quality of life in patients with recurrent aphthous stomatitis treated with a mucoadhesive patch containing citrus essential oil', Patient Preference and Adherence. doi: I0.2147/PPA.SI06530.

Mastrodi Salgado, J. et al. (2012) 'Increased Antioxidant Content in Juice Enriched with Dried Extract of Pomegranate (Punica granatum) Peel', Plant Foods for Human Nutrition. doi: I0.1007/sI II30-0II0264-y.

Mphahlele, R. R. et al. (2016) 'Effect of drying on the bioactive compounds, antioxidant, antibacterial and antityrosinase activities of pomegranate peel', BMC Complementary and Alternative Medicine doi: I0.II86/sI2906-0I6-II32-y.

Nauli R.R. (2010). Pengaruh pemberian ekstrak kulit buah delima putih (punica granatum linn) dan ketokonazol $2 \%$ terhadap pertumbuhan candida albicans secara in vitro pada kandidiasis vulvovaginalis. Fakultas Kedokteran, Universitas Diponegoro.

Samprasit, W. et al. (20I5) 'Fabrication and In Vitro/In Vivo Performance of Mucoadhesive Electrospun Nanofiber Mats Containing $\alpha$-Mangostin', AAPS PharmSciTech. doi: IO.I208/sI2249. 0I5-0300-6.

Shaikh, R. et al. (20I I) 'Mucoadhesive drug delivery systems', Journal of Pharmacy and Bioallied Sciences, doi: I0.4103/0975-7406.76478.

Verma, N. and Chattopadhyay, P. (20I I) 'Polymeric Platform for Mucoadhesive Buccal Drug Delivery System: a Review', International journal of current pharmaceutical research.

Wahid, R., Darmawan, E. (2020). 'The Effect of Black Seed Oil as Adjuvant Therapy on Nuclear Factor Erythroid 2-Related Factor 2 Levels in Patients with Metabolic Syndrome Risk', Iranian Journal of Pharmaceutical Sciences, I6(I), pp. 9-I8. 
doi: I0.22034/ijps.2019.94568.I48.

Wirawan, E. and Puspita, S. (2017) 'Hubungan $\mathrm{pH}$ Saliva dan Kemampuan Buffer dengan DMF-T dan def-t pada Periode Gigi Bercampur Anak Usia 6-I2 Tahun', Insisiva Dental Journal: Majalah Kedokteran Gigi Insisiva. doi: I0.18196/di.6I77. 